\title{
TV/Series
}

Hors séries 1 | 2016

Lost: (re)garder l'île

\section{Lost, or a Guide for the Lovesick}

\section{Pacôme Thiellement}

Translator. Brian Stacy

\section{OpenEdition}

\section{Journals}

Electronic version

URL: http://journals.openedition.org/tvseries/4978

DOI: 10.4000/tvseries.4978

ISSN: 2266-0909

Publisher

GRIC - Groupe de recherche Identités et Cultures

\section{Electronic reference}

Pacôme Thiellement, "Lost, or a Guide for the Lovesick » TV/Series [Online] Hors séries 1 | 2016 ,

Online since 01 December 2020, connection on 05 December 2020. URL : http://

journals.openedition.org/tvseries/4978 ; DOI : https://doi.org/10.4000/tvseries.4978

This text was automatically generated on 5 December 2020

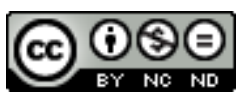

$T V /$ Series est mis à disposition selon les termes de la licence Creative Commons Attribution - Pas d'Utilisation Commerciale - Pas de Modification 4.0 International. 


\title{
Lost, or a Guide for the Lovesick
}

\author{
Pacôme Thiellement
}

Translation : Brian Stacy

In a work on Bouvard and Pécuchet, Raymond Queneau singled out two defining lines in the History of the novel: that of the Iliad, and that of the Odyssey.

Every great work is either an Iliad or an Odyssey, the odysseys being far superior in number than the iliads: the Satiricon, The Divine Comedy, Pantagruel, Don Quixote and of course Ulysses are odysseys, that is to say, des récits de temps pleins. The iliades are, on the contrary, searches for lost time: facing Troy, on a deserted island or at the Guermantes'1.

Lost falls along both, but more importantly, it splits its narrative content into two levels: a contemplative level, that of the Brahmins, of the priests, the story of the election to become protector of the island, which is also a story of discipleship and obedience; and another level, active but true to sacred principles, that of the ksatriyas or knights, the story of "adventures" seeking the return of a loved one, Desmond's storyline. The first throughline finds echo in Farid al-Din Attar's The Conference of the Birds, the stories of Sohrawardi, and Daumal's Mount Analogue; the second draws on The Odyssey and tales of chivalry.

The first throughline, recounting the election of the island's protector, deals with the island's discovery, the story of Jacob and his brother, the red herring that is the Dharma Initiative (the jumble of hypotheses involving sci-fi subplots, time travel, etc.), the story of the Others, Ben and Widmore's rivalry, Ben and Locke's rivalry, Locke's and Jack's sacrifices, and Hurley's election. One might add flashbacks featuring characters' backstories in relation to an item or feature, often topographical, which serve as a symbol of the island or as a secondary setting (Thailand for Jack, Uluru for Rose and Bernard, etc.). From the second season onwards though, a "love" line is snuck in under the radar. Said throughline is oblique, serpentine and zigzagging, upsetting the coherence of the main storyline: every character is discreetly confronted with love in their primary individual storylines. Jack loves Kate, which takes a back seat to his lifeline to her sacrifice for the island's survival. Juliet loves Sawyer, but her love never takes center stage within the story, being only implied and depicted during interludes. 
4 All the characters are at first part of Jacob's tapestry. All but one, who, to my knowledge, never cross paths with Jacob throughout his story, nor shows any concern at the mention of Jacob's name, living as he does in another Lost dimension: Desmond.

From the moment he steps into Lost's storyline, Desmond is clearly positioned along a different throughline than the other characters. Unlike everybody else, he sets out to achieve more than the regaining his sense of purpose, and for him, the island isn't a place where he can unlock his untapped potential, despite being twice shocked by electromagnetic discharges in Seasons 2 and 6, events that prove crucial in settling the plot. The island is, in his life story, only an "adventure" before returning to his lover. Desmond's story supersedes that of the passengers on Oceanic Flight 815. This is also why "the rules do not apply to him". It is said of love that it knows no laws, and that's what makes Desmond special. "If reason were a lover's guide, no swimmer would come ashore alive" (Attar)2. One might even draw a superficial distinction between traditional metaphysics (Indian, Persian, Egyptian, Chinese, Jewish) and those appearing more recently (Christianity, Islam, late Buddhism, Japanese or Tibetan).

The former undoubtedly concern themselves with Laws and rules: the Laws of Manu in India, for instance, which recall the role of Jacob and later Hurley as universal lawmaker. An enigmatic Book of Laws appears in the "Cabin Fever" episode, part of the "test" to identify the chosen one; Mr. Eko's monologue in the "What Kate did" episode also comes to mind:

Long before Christ, the king of Judah was a man name Josiah... at that time, the temple where the people worshipped was in ruin and so the people worshipped idols: false Gods. And so, the kingdom was in disarray. Josiah, since he was a good king, sent his secretary to the treasury and said "We must rebuild the temple. Give all of the gold to the workers so that this will be done." But when the secretary returned he had no gold. And when Josiah asked why this was the secretary replied "we found a book." What the secretary had found was an ancient book: The book of Law. You may know it as the Old Testament. And it was with that ancient book, not with the gold, that Josiah rebuilt the temple.

7 The monologue above coincides with the Lost's main narrative throughline, the reconstruction of the Temple, the central place of initiation which grants and safeguards the spiritual existence of mankind through the acceptance of rules; a narrative designed to teach the characters obedience. As Eloise says: "You don't do it because you want to. You do it because you' re supposed to. "This line is similar to the one that frames Attar's The Conference of the Birds: the search for the universal lawmaker, a search that merges with his replacement.

8 The second metaphysical expressions (Christianity, Islam, late Buddhism) are conversely characterized by individual action, and the individual search for salvation through the experience of love, even if it alternates between personal love and universal compassion, and, through this second term, overlaps with the older metaphysics. "A spectacular, consciousness-altering love" as Charlie says: "Blonde, rapturously beautiful, and I know her. We're together. It's like we've always been, and always will be." We must think of St. Paul and his opposition between the Law and love, or the path of the Sufis who, like al-Hallaj, abandoned the legalistic expression of Islam to offer themselves as a sacrifice of love to the divinity, even if it meant embracing the mantle of heresy.

9 Desmond's "life story" is packed into a handful of episodes, but its very peculiar focus, incredibly rich structure and the intense emotion felt by viewers instantly made it a 
pivotal part of the story: it comprises the finale of Season 2, "Live together, die alone"; episode 8 of Season 3, "Flashes before your eyes"; "Catch-22", episode 17; the 5th episode in Season 4, "The Constant"; and the 11th episode of the last season, "Happily ever after". Arguably to be included is "Jughead", regarded by some as a Desmondcentric episode in Season 5, though its story revolves as much, if not more, around Daniel Faraday and his parents' experience on the island. Moreover, through alternating sequences covering two different time periods on and off the island, and then both simultaneously, the subject of who or what the episodes in Season 5 are centered on is far from straightforward.

In "Happily ever after", elements from three out of the other four episodes are quite openly referenced: the stadium in "Live together die alone"; McCutcheon's glass scene and Widmore's office painting from "Flashes before your eyes" and the conversation with Eloise; the exchange about time travel with Daniel that sets up "The Constant" and the presence of George Minkowski. Add to this the tense relationship with Charlie that punctuates Season 3 and the image of Charlie's hand in the series' final episode, "Through the looking glass", bearing the inscription "Not Penny's boat" that unites the two story lines, introduces Penelope Widmore's character into the main story and sets the tone for Season 4 - even though Penny never makes it to the island (rather extraordinary for such an important character in the series). Penny is, in the church of the series finale ("The End"), the only character who never travels to the island, even dead or, like Christian Shephard, in the form of a fake ghost or apparition of the Nameless Man.

11 Three of these five episodes, "Flashes Before your Eyes", "The Constant" and "Happily Ever After", clearly stand out from the others, subtly disclosing shifts in the narrative path, and consciously traversing Lost's narrative layers: "Flashes Before your Eyes" is a flashback experienced as a journey into the past; "The Constant", a round trip across two timelines, in which moments in the present are experienced as flashforwards; finally "Happily Ever after" is a flash-sideways, or an episode taken from life and after death, but explored by a character during their lifetime -- itself transformed by the flash-sideways. In it, through an anamnesis effect (Charlie's submerged hand), the main story of Lost begins to resurface, which it continues to do until the end of the season.

It should also be stated that the flashbacks in "Live together die alone" introduce the character of Charles Widmore, thereby bringing in characters from outside the island's narrative, or the relationship, hitherto only symbolic or allegorical, between the characters' flashbacks and the relationship between themselves and the island. These flashbacks posit the never-fully-explained idea that Desmond was somehow manipulated by Penny's father into finding the island. If we consider that everything etched into the lives of the protagonists is there to put them on the island together-Richard Malkin's intervention in Claire's life, Isaac de Uluru's intervention in Rose's life, and even M. Kwon's threats on Jin's life - in Desmond's case, this is compounded by the fact that Eloise Hawking makes this symbolic etching explicit, denying him access to another narrative line, and hinting at possible interventions by Widmore, Brother Campbell, and even Libby and her boat.

We're often given the impression that the characters featured in flashbacks are preparing the cast of Lost for life on the island, that they know about things that the survivors don't. Although Jacob intervenes concretely in the lives of the "candidates" in "The Incident" and Richard and Matthew Abaddon seem to have "tracked down" Locke 
for a long time in "Cabin Fever", such interventions don't appear to be limited to a handful of characters; all of the characters in the flashbacks were potentially necessary for the "candidates" to learn, to confront them with the mystical obedience that perhaps forms Jacob's most prominent character trait. Everyone eventually comes to accept this obedience, except Desmond, who always responds negatively to its implications: "The island is not finished with you," Eloise tells him. "I'm finished with the island" is Desmond's answer. And if, within the framework of Desmond's storyline, outside characters' interventions look more like a ploy or scheme than as a token of fate, this is because his story is driven by his reunion with Penny.

Desmond's story and its theme of "returning to one's lover", is of course an implicit reference to The Odyssey, hence the name Penny, short for Penelope. The Penelope character in The Odyssey is eventually split into two characters in Lost: Penny who must retrieve Desmond (and who ends up finding her more than the other way around) and the tapestry woven by Odysseus' wife in The Odyssey which lands in Jacob's hands making mirror figures out of the two characters due to their demure, observant behavior, their role as guarantors of global order and the place of spirituality in the world. Penelope is a priestess. She is a protector of the spiritual order expressed in the form of love - for the faithfulness of her love, for her "constancy", for her self-sacrifice and her heroism. This makes her a core pillar of the narrative on the same level as Jacob, even though her intercession is of a different nature.

There' s a sizeable difference between 'Flashes before your eyes' and 'The Constant' in terms of the way their two lines are articulated. The first episode forces Desmond, through Widmore and Eloise, onto the main line as the island's protector, as well as through his role as the temporary protector of the Swan station, sidelining his "love line" in favor of a Brahminical resolution. "Flashes before your eyes" vindicates Eloise's words and shows Desmond to be tentatively yielding to the main narrative. "The Constant", on the other hand, affirms, thanks to Charlie's previous and Daniel's present-day interventions - the power of Penny's love, turning it into a self-determined act and allowing it to play out across two different timelines, opening the series to another possible resolution than the one associated with protectorship of the island. But above all the simultaneous "I love you" of Desmond and Penny at the end of the episode heralds the final season's epiphanies and anamnesis affecting the other characters. One can say that "Flashes before your eyes" sets Desmond's story squarely within the series narrative framework as experienced from Jacob's point of view, while "The Constant" sidetracks the entire series towards Desmond's romantic resolutions.

In the flash-sideways' subtle realm of manifestation, the middle space separating life and death in the Hindu, Persian or Buddhist traditions, Desmond is a well-rounded and fulfilled man, professionally accomplished but loveless. It is following his romantic anamnesis with Penny that he decides to "show" the other characters the reality of their condition, splitting Desmond's character at the end into two psychic realities both akin and opposite each other: that of the island, which claims that reality is illusory, and that of the flash-sideways, which knows that the latter to be a reflection of reality, albeit one elevated to a higher epiphanic plane.

These two illuminations occur simultaneously and structure Lost's whole otherworldly ending, encapsulating the two above-mentioned lines: that of proctorship of the island, to which Desmond is a stranger, and that of "returning to one's lover" as an image of sacred love to which only Desmond shall have access in this world. One of the 
characteristics of Season 6 of Lost is of course this dual nature, the story's second birth, like a flower blossom - a symbol of love - with which we must associate Sawyer's new moniker during his three-year stint with the Dharma Initiative: Jim LaFleur. The flower "la fleur" is the symbol of a love that manages to "grow" between Sawyer and Juliet in the story's cracks and crevices.

But above all, Desmond's flash-sideways move redefines those of the other characters, for whom love takes on an image of the untapped potential the island puts within their reach. The island appears through love - or rather it is a common principle of which the island and love form two mutually exclusive expressions. Love in Lost, like the characters' "fates", is hindered by what conditions them externally and internally. Acts driven by love are analogous to the initiatory acts, in the sense that they form a junction between the visible and invisible worlds. For Jack and Kate, Charlie and Claire, Sayid and Shannon, Hurley and Libby, Sawyer and Juliet, the island that enables them to find each other - not to mention Sun and Jin, since they were a missing couple. Only Rose and Bernard remain unchanged throughout the story, very quickly devoting themselves only to settling on the island and living together. Just like Vincent the dog, they completely disappear from the narrative between the end of Season 5 and the Season 6 finale. Viewers are made to understand that they settled down, indifferent to the characters' actions, as they have somehow "left the narrative" and "withdrawn" from the story.

The characters' love stories almost always appear as interludes within the narrative, especially given that they seldom involve a single love. Flashbacks tell of Jack and Sarah's marriage, separation, and the slide into deeply disturbing jealousy - Jack even suspects Sarah of engaging in a covert relationship with her father Christian (this plot point is never properly clarified - viewers are only afforded Jack's point of view, and so we're never shown Sarah's new lover and father of her future child; the character of Sarah eludes us as much as she does Jack). Flashforwards tell the story of Jack and Kate's union, their attempt to live together and Jack's slide into alcohol-fueled jealousy. But the present-day island offers little room for their love story as such, sticking to their elaborate courtship, and especially to Kate's comings and goings between Jack and Sawyer, since Kate seems unable to definitively choose between them.

Sawyer's flashbacks show him having casual relationships with many women, including the character of Cassidy with whom he will have a daughter he doesn't raise. Although on the island he is predominantly attracted to Kate, his one true love was probably Juliet, but, in a twist of the narrative, we don't find out anything about the three years they spent together. As soon as the story returns to the present tense, their relationship is torn apart by Kate's return.

21 Kate's flashbacks show her reunion with her childhood sweetheart, Tom Brennan, and his death; her marriage (under the name Monica) to a policeman named Kevin; a relationship (under the name Maggie) with a bank robber named Jason. In the episode "The End", as she leaves the island, Kate "chooses" Jack by kissing him passionately in front of Sawyer. Again, their love is decreed in advance to be impossible. The characters of Jack, Kate, Sawyer or Juliet are presented as already broken at the outset of the story, suffering from an irreparable loneliness of the soul.

Sayid's flashbacks and flashforwards primarily revolve around his relationship with his childhood friend Nadia, with whom he spends a large part of his life (he searched for her for seven years, from 1997 to 2004, and found her when he returned from the 
island; whereupon he lived with her for nine months until she was murdered by a Widmore employee). However, his defining romance will be his escapade with Shannon, unfolding on the island over the course a few days. Hurley hardly has the time to meet Libby before she's killed off by Michael. Charlie has a seemingly platonic relationship with Claire throughout his time on the island. As for Locke, there is Helen, a woman who meant a lot in his life, but who has already passed on when Locke returns to the mainland. Helen doesn't appear among the characters present in the church, making Locke, when all is said and done, a lonely heart whose spiritual relationship with Jack conditions the anamnesis.

There still remains the peculiar case of Sun and Jin, who are one and the same in Jacob's eyes. Their pre-crash life is that of two lovers driven apart by the nastiness of Sun's father, embittering Jin so much that he hates himself and violently lashes out at Sun, who is having an affair with Jae Lee. The island binds them in a unique and lasting way, with their love overtaking even their sense of responsibility towards their daughter Ji Yeon. But all these loves are conditioned and limited: they exist but do not exceed a limit, which is their submission to the island. Jack and Hurley will successively volunteer for the role of protector of the island. Sayid, Sun and Jin will be slain by The Nameless Man in his plan to assassinate the "candidates" chosen by Jacob. Sawyer and Kate leave the island at the end of the story, but we know from the flash-sideways that their most meaningful relationships were with Juliet and Jack, respectively.

It is in the manifestation of the subtle world that love becomes the driving force of the narrative and a venue for anamnesis. The lovers therefore replace the island as a pole of orientation, given that it vanishes in the very first scene and sinks to the bottom of the ocean. Moreover, if Jacob created the tapestry serving as a synecdoche of the first five seasons and if the sixth season is written by the characters themselves, in the absence of a primordial lawmaker, then it must be specified that Season 6, divided into two worlds, presents one world beholden to logic, and even a kind of order based on love.

By a mirror effect, Desmond could be said to have authored the story, for he decides to give the characters the experience of anamnesis by confronting them with the "loves" that mattered most in their lives: Hurley with Libby, Sayid and Shannon, and so on. Desmond thus becomes the Khizr or Manu of the subtle realm of manifestation. He morphs into a prophet of love. An allegorical dimension can be found in the main narrative of Lost linking it to the initiatory narratives of Sohrawardi or Attar (the narrative of Western exile, the search for the island outside the conditions of space and time), but it is Sufism, the spirit of the troubadours and faithful lovers that will enable us to grasp what underlies the flash-sideways, namely the connection between profane love and divine love. Each character thus has a soul mate in whom we see the epiphanization of divinity. Battlestar Galactica (Sci Fi, 2003-2009) had already explored this topic before Lost via the relationship between Gaius Baltar and Cylon 6 "Caprica", each guided by an angelic aura in the likeness of the other, with the deity epiphanizing for both in the form of the beloved until they reunite, when Gaius at last demonstrates his courage and self-sacrifice. The remarkably clever way in which Battlestar Galactica presented the "theme of love" through the most cowardly, pretentious, complacent and calamitous character in the series - the one who "deserves" love the least, but who is, at heart, like Desmond (for whom "the rules don't apply"), the character with whom the 
viewer is least likely to identify. Therein lies perhaps the key to this section of the story. Here we quote Rumi:

In the beginning, when I listened to love stories

I left my soul, my heart, my eyes in its path.

I used to say: 'Maybe the lover and the Beloved are two.

They were both one, I was the one who was seeing double ${ }^{3}$.

The persona of the island's spiritual protector is notoriously chaste: Jacob, and perhaps even Ben and Hurley, are virgins. Richard's wife died long ago. Locke is a kind of widower too, living "separated". Almost all of the characters have appalling excuses for fathers. Only the fathers of Jin, Hurley, and, after a laborious process of forgiveness set in the other world, Jack, are cast in a congenial light. And almost all the characters are childless: Jack, Kate, Charlie, Sayid, Shannon, Boone, Ana Lucia, Libby, Juliet, Daniel, Charlotte, Miles, and the list goes on. This unhappy loneliness and sterility are "markers" for Jacob, who explains to the "candidates" in the episode "What they died for": "You were all flawed. I chose you because you were like me. You were lonely. You were looking for something you couldn't find out there. I chose you because you needed this place as much as this place needed you." Viewers identify with Lost based on their ontological loneliness, their lonely soul.

"The Sufi has no consciousness of being a sinner," writes Henry Corbin: "he is an exile; and this distress, this nostalgia, which he shares with Gnostics throughout the ages, means that what he calls for is a messenger showing him the way home, because there is no other desirable or conceivable future for him than to return to the place of his origin, to be home ${ }^{4}$. The Gnostic dimension of Lost lies in the fundamental solitude of the "candidates", strangers in this world, strangers in a strange land. It is this solitude that Desmond ends in the flash-sideways by "showing them something". And this is why, to the story of the Gnostic of Light that is Sohrawardi, one must substitute that of the faithful lover. Hence Ruzbehan Baqli Shirazi to whom God whispered "Look for me in the mystical station of love $e^{5}$."

"That's when I took up residence in the world of Beauty," wrote Ruzbehan, who fell for a young female singer from Turkestan: "Burned by soul-crushing love for Beauty divine, I emigrated to the creaturely world of the ephemeral ${ }^{6}$. One is hard-pressed to find the story of a Sufi not having experienced the torments of love, considered as an uplifting trial: Rumi feels unconditional love for Shams ed-Din driving him to produce his poetic oeuvre. Attar wrote a moving Diwan from which the collection The Seven Cities of Love is taken. It is a young girl, Nizham, who causes Ibn Arabi to have a theophany while he's making a pilgrimage to Mecca. Ibn Arabi sees Nizham as an earthly manifestation of the Sofia Aeterna: "It is in the book of human love that one must learn to read the rule of divine love."

What can be said of this profane love, imbued with a spiritual glow, is that it lies firmly outside of Time. It is biologically sterile (no known mystical love leads to the procreation of a child), and indifferent to "gender" (it can appear either as a female figure, Nizham, or a male figure, Shams, without being treated any differently). It is part of an experience of the original androgynous figure found previously in Plato's Symposium, according to Aristophanes:

Each one of us is a fraction of a human being whose other half exists, since this being has been cut as one cuts the soles, and has split. Each one, of course, is in perpetual search of his other half?. 
As well as in Socrates' evocation of Diotima, a "distinguished Pythagorean" who educated him about love:

Love is an intermediary between the mortal and the immortal. He conveys to the gods what comes from men and send to men what comes from the gods. In the first place he is always poor, and he's far from being delicate and beautiful... instead he is tough and shrivelled and shoeless and homeless, always lying on the dirt without a bed, sleeping at people's doorsteps and in the roadsides under the sky, having his mother's nature, always living in Need. On the other hand, he is happy and in possession of the good and the beautiful. He is a schemer after the beautiful and the good; he is brave, impetuous, and intense, an awesome hunter, always weaving snares, resourceful in his pursuit of intelligence, a lover of wisdom through all his life, a genius of enchantments, potions and clever pleadings ${ }^{8}$.

Love is therefore a bridge enabling that which is conditioned and determined to envisage the unconditional and the indeterminate. Love is found in the poems of the troubadours, Dante's Beatrice, Petrarch's Laura, and split into a young man and a "dark woman" in Shakespeare's Sonnets. It is from this love that the flash-sideway narrative of Lost flows: it is not a matter of settling down into love, nor of constructing a love story. Love is instead a "rapture of the will" (Eloise speaks of a "violation" in the episode "Happily ever after") producing the anamnesis of our divine co-identity. The reason is obvious: love is the sign that solitude is the bottom line, that solitude comes to an end, which is the mark of the Gnostic on this world. Like Desmond, we should consider love as divine love's "failsafe key". Henry Corbin says the following:

God himself is the source of the reality of Eros, prohibiting its double desecration: that of libertinism, which is its profanation, and that of asceticism, which by calculation or by a congenital "miserabilism" is its negation".

This is also implied in the chaste nature of Lost's romances: Hurley/Libby, Charlie/ Claire, as well as Desmond/Penny and James/Juliet are never seen behaving in an erotic way - Jin/Sun and Sayid/Shannon are in contrast portrayed in an infinitely gentle and affectionate light.

Only Jack and Kate feel something like "untamed love", but out of all the couples in Lost, they're the ones who struggle and fight the most, who have the hardest time becoming One - and achieving a unifying fusion of their respective hues through erotic alchemy. Ruzbehan says:

Love is the influence of the Red Sulphur of Divine Magnificence projected into the light of the soul's eyes. Thus since pre-eternity the alchemical operation has hidden a soul within the soul of the soul. It is for this reason that in the two persons of the lover and the beloved, love is in fact, through the dyeing of the unitive fusion, one and the same perfect monochromy. The mystical reality immanent to love makes you hear a certain note, if you know how to lend an ear ${ }^{10}$.

And so we have to go back to the first snapshot of anamnesis: Charlie's hand with the inscription "Not Penny's Boat" appearing in the last episode of Season 3, "Through the looking glass", and causing the whole story to change: since it is at the end of this season that the series, reaching its center or middle (with the intersecting influences of Lewis Carroll, the Beach Boys and the Beatles' song A Day in the life), is transformed.

"Not Penny's Boat" is: a sign that Charlie has not sacrificed himself for what he believed (Claire will not leave the island with Aaron on the boat upon arrival, but three years later in Lapidus' plane; the boat is not intended to "save" the passengers of the Oceanic Flight 815; it will lead, through Kimmy's murderous intervention, to many deaths: Alex, Daniele, Karl, Michael, and others); the indication of a "Pyrrhic victory" in Jack's fight 
against the Others (Jack did decimate a large part of Ben's team, but doing so nevertheless resulted in the arrival of an even deadlier team); the beginning of a permanent falling out between Jack and Locke and the forming of two camps (those who planned to leave, led by Jack; those who don't trust the boat, led by Locke); finally and most importantly, the announcement that Penny isn't coming to the island, in other words the symbolic affirmation of two irreconcilable orders, that of obedience to principles and that of love.

And it is this same hand which, in the sixth season, introduces a series of anamnesis: from this image, and immersed in baptismal water, Desmond himself will become aware of his eternal love for Penny and will lead the other characters to their respective anamnesis: Hurley and Libby; Sayid and Shannon; Sun and Jin; Charlie and Claire; Locke opposite Jack (but already Ben opposite Locke); Juliet and Sawyer; Kate opposite Aaron; finally Jack with Kate then with his father Christian. In the end, in the church, they are all "connected" by a love epiphanizing itself simultaneously in the figure of love and in a cosmic love that encompasses them all, an unconditional reconciliation.

This is the dual nature of the outstretched hand gesture - the Khamsa, or "hand of Fatima," so well known in the Arab world as a protection from evil. Both defense and protection. Defense in the sense also of an incompatibility between two worlds: the island and Penny's world. Both worlds are exclusive (and besides, it is no wonder that Desmond meets Penny after his expulsion from a monastery; he is expelled from a priestly role to which he has no legitimate claim). And protection because it affirms a supreme connection in the other world: the correspondence or analogy of profane love and sacred love. In The Need for Roots, Simone Weil writes:

For the people have a monopoly of a certain sort of knowledge, perhaps the most important of all, that of the reality of misfortune; and for that very reason, they feel all the more keenly the preciousness of those things which deserve to be protected from it, and how incumbent it is on each of us to cherish and protect them. Melodrama reflects this popular state of feeling. Why it happens to be such a dreadful literary form would be worth while taking the trouble to examine. But far from being a false form of expression, it is very close, in a certain sense, to reality ${ }^{11}$

Following in the tradition of Douglas Sirk, Rainer Werner Fassbinder and Lars Von Trier, Lost joins the exploration of melodrama as a "true genre". Lost has even pioneered the initiatory melodrama: through the casting a fresh gaze, the combined sufferance of the characters in this world becoming stages in their Brahminic initiation. Suffering does not impart any knowledge in itself, it has no value, but there is a "sound use" of suffering which is the acquisition of a higher consciousness, and this is what Lost's story achieves. The mass of betrayals endured by Jack, Sayid, Locke or Kate, all the traumatic events invariably fuel their actions on the island, towards the island, on behalf of the island. With one exception, of course: their love, which is not part of this initiation and remains on its own, "aimless", "without purpose", "unrequited". Their love for which "the rules do not apply". The same holds true for viewers: Lost's main narrative is about gaining a new perspective, a "perfect perspective". This is the meaning of Lost's opening and closing shots: the eye, the symbol of Lost. The secondary narrative is that of Charlie's "hand", which stands in the middle of the story. Both defense and protection, the hand is a reminder that meaningless suffering is the lot of us all, that the future never looks like what we expected, that "Penny's boat won't come looking for us," nor will grace, the light of 
love, or epiphanic joy. Charlie's hand serves to protect the TV series itself. It acts towards Lost like Khamsa or "Fatima's hand", outstretched to protect the viewer. not only does the series put us in the contemplative seat of the manu, Jacob, in the background, protector of the TV series, but, through the hand, it also strives to "show us something" relevant to us, an anamnesis shot through with deep affection, the love we have for Lost's characters and which makes it hard to revisit many of the show's scenes without wiping away tears. In the end, the love that the characters have for each other is also the love that they have for us and that we have for them. And, as in the Beatles' song, "the love you take is equal to the love you make". In the end, what counts is the sense of belonging we have to each other, and the idea that in other circumstances, under other auspices, we could have conveyed the love we have for each other, free of anger, jealousy, sadness, bitterness. Ruzbehan Baqli Shirazi says the following:

Contemplation of the cosmos is the qibla of pious devotees; contemplation of human beauty is the qibla of the love's faithful. The powerless men of religious conformity criticize us. The Signs of creation in the heavens are most sublime, they say. Why do you not contemplate them? Surely there are Signs in the heavens, and the Signs show the way to inconsolable hearts. But on the human face rises the sun of the theophany of the Essence and Divine Attributes, for it was through human beauty that love entered this world. Love for beauty is seeing eternal existence with the very eye of $\operatorname{God}^{12}$.

In this, Jacob's role is no more ours than Desmond's. Or rather: as a Lost viewer, we're perpetually somewhere in the middle. We are those who watch and obey, the pious devotees, and those who love and act, love's faithful. We stand between contemplation of the cosmos and contemplation of human beauty. A hundred and twenty-one episodes have taught us to see and to love. In return, we have seen and loved Lost in 121 different 
ways. And we have learned to love our friends in 121 unique ways. One day, we will find our beloved in their essence; we will stand rejoicing next to them, for a few moments of eternity, moments that we will have created to reunite before we go. On that day, we will also know what we owe to Lost as a modern guide on love's essence, a modern-day treatise on chivalry for lonely souls struck down by love.

\section{NOTES}

1. Raymond Queneau, "Bouvard et Pécuchet", Bâtons, chiffres et lettres, Paris, Gallimard, Folio, 1965, p. 110.

2. Farid al-Din Attar, Les Sept cités de l'Amour, Paris, Albin Michel, 2013, p. 27.

3. Djalal ad-Din Rumi, Rubâi'yât, Paris, Albin Michel, 1993, p. 178.

4. Henry Corbin, En Islam iranien, Les Fidèles d'amour, Chiisme et soufisme, tome 3, Paris, Gallimard, 1972, p. 13.

5. Cited by Henry Corbin, En Islam iranien, Les Fidèles d'amour, Chiisme et soufisme, tome 3, Paris, Gallimard, 1972, p. 60.

6. Cited by Henry Corbin, En Islam iranien, Les Fidèles d'amour, Chiisme et soufisme, tome 3, Paris, Gallimard, 1972, p. 71.

7. Plato, "Le Banquet", Phédon, Le Banquet, Phèdre, Paris, Gallimard, 1991, p. 121.

8. Plato, "Le Banquet", Phédon, Le Banquet, Phèdre, Gallimard, 1991, coll. Tel, p. 135-136

9. Henry Corbin, En Islam iranien tome 3 Les Fidèles d'amour, Chiisme et soufisme, Gallimard, coll. Tel, 1972, p.21

10. Cited by Henry Corbin, En Islam iranien, Les Fidèles d'amour, Chiisme et soufisme, tome 3, Paris, Gallimard, 1972, p. 101

11. Simone Weil, L'Enracinement, Paris, Gallimard, 1949, Folio, p. 224-225

12. Cited by Henry Corbin, En Islam iranien, Les Fidèles d'amour, Chiisme et soufisme, tome 3, Paris, Gallimard, 1972, p. 96

\section{ABSTRACTS}

By inventing initiatory melodrama, by constructing a perfect gaze and by telling different love trajectories (be they perfect or imperfect), Lost embodies two things simultaneously for its spectator. Through the motif of the eye, the series puts us in the contemplative place of Jacob as protector of the series; through the hand, it attempts to make us experience an anamnesis based on great affection and the love we feel for the series' characters. In the end, the love that the characters feel for one another is also the love they feel for us and that we feel for them.

En inventant le mélodrame initiatique, en construisant un regard parfait et en racontant différentes trajectoires amoureuses (parfaites ou imparfaites), Lost incarne deux choses 
simultanément pour son spectateur. Par l'œil, Lost nous met à la place contemplative de Jacob, en retrait, gardien de la série; par la main, elle tente aussi de nous faire vivre une anamnèse qui passe par la grande affection, l'amour qu'on a pour les personnages de la série. À la fin, l'amour que se portent les personnages, c'est également l'amour qu'ils nous portent et que nous leur portons.

\section{INDEX}

Mots-clés: Lost, amour, mélodrame, contemplation, gardien, épiphanie, anamnèse, flashsideways, initiation, orientation, regard

Keywords: Lost, love, melodrama, contemplation, protector, epiphany, anamnesis, flashsideways, initiation, orientation, gaze

\section{AUTHORS}

\section{PACÔME THIELLEMENT}

Pacôme Thiellement is a writer born in 1975 in Paris. Among his books: Poppermost (MF, 2002); La main gauche de David Lynch (PUF, 2010); Les mêmes yeux que Lost (Leo Scheer, 2011) ; Pop Yoga (Sonatine, 2013); Cinema Hermetica (Super-8, 2016).

Pacôme Thiellement est un écrivain né en 1975 à Paris. Parmi ses différents livres : Poppermost (MF, 2002) ; La main gauche de David Lynch (PUF, 2010) ; Les mêmes yeux que Lost (Leo Scheer, 2011) ; Pop Yoga (Sonatine, 2013) ; Cinema Hermetica (Super-8, 2016). 